\title{
砂磉土の高圧下での粒子破砕と粘着力 の発達について
}

\author{
萩原 敏行 ${ }^{1} \cdot$ 北澤 浩二 ${ }^{2} \cdot$ 日下部 治 $^{3}$ \\ 1 正会員 工博 群馬大学助教授 工学部建設工学科（テ376 群馬県桐生市天神町 1-5-1） \\ 2正会員 工修 タイイヤコンサルタント（株）（テ171 東京都豊島区南池袋2-34-5） \\ ${ }^{3}$ 正会員 Ph. D. 広島大学教授 工学部第四類（建設系）（テ724 広岛県東広岛市鏡山1-4-1）
}

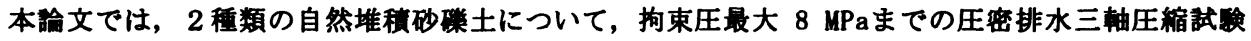
を実施し，せん断中にボンド楼造が形成された結果を述へている. 試䤅試料は，いずれも火山性堆 程物からなる粒子破碎性の强い材料である．高拘束圧下でのせん断試耠後供試体について一誎圧縮

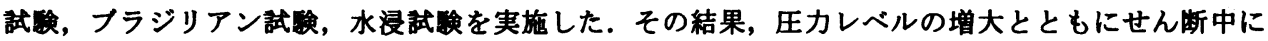
発達する粘着力の大きさが增加し，また高圧での粘着力の発達には，粒子破砕が大きく影制してい ることが明らかにされた。
\end{abstract}

Key Words: naturally deposited soils, bonding, particle breakage, cohesion, high pressure

\section{1．まえがき}

著者らは, 2 地点の工事中のニューマチックケ ーソン内を利用して実施された直接基礰の現場载 荷試験1)，2）のサイトより，自然堆積砂磁士を乱 さない状態で採取し一連の力学試験を行い,それ らの強度・変形特性について検討した3)、4)。また, 同一サイトより採取した乱した試料による力学実 験から，試料の摚乱の影锌について定量的な評価 を行った結果, 自然堆積砂碟の強度・変形特性の 理解には, 粒子破砕, 異方性, 粘着力に代表され る土の構造特性4)を正しく評価することが重要で あることが明らかにされた．特に，現場载荷試験 より得られた極限支持力を解釈する上で, 高圧力 を受けた基礶直下での粒子破砕ならびに強度定数 における粘着力の精度良い評価が重要であること, またその評価の難しい点についても指摘された2).

粒子破砕と粒状材料の力学的特性の関俰につい

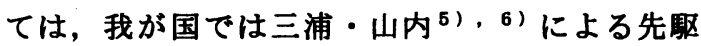
的研究により明らかにされている. 豊浦砂で行っ た拘束圧 $1 \mathrm{MPa}$ 越える高拘束圧下での排水三軸 圧縮試験の結果より，粒子破砕が粒状材料の圧
縮・せん断特性に大きな影䇾を及ぼすことを定量 的に明らかにしている. また, 三浦 ${ }^{7)}$ は, 模型 砂地盤中において杭の载荷試験を実施し, 杭先端 付近の砂の粒子破砕と支持力との関係を調べてい る. その結果, 砂の粒子破砕が, 要素の高圧三軸 圧縮試験で認められた場合と同様に, マスとして

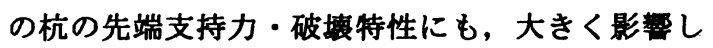
ていることを示している.

自然堆積土に含まれるボンド構造に関しては, 近年その重要性が改めて指摘され始めており8), 実験室内での高温圧密養生によるセメンテーショ ン効果の再現についての研究も進められている ${ }^{9)}$. また, $1100^{\circ} \mathrm{C}$ の高温下で砂とカオリンを混合 させた砂粒子間に, ボンド構造が発達することも 指摘されている(0).

地震工学の分野においては, 自然砂地盤の有す る僅かな粘着力が液状化現象に大きく影䇾し11), また斜面安定解析の精度には, 粘着力の評価が敏 感であることも明らかにされている12)。

不飽和土の安定問題では, 低拘束圧下の条件で のせん断強度，特に粘着力を精度良く評価するこ とが重要であることが指摘されている13)，14)。 
また，不飽和土のせん断試験結果では，見かけの 粘着力は含水比の関数となることが報告されてい る(5), 16)。

低拘束圧のせん断時の強度定数 $\mathrm{c} ， \phi$ のモビラ イズについて, Bjerrum 17)は, 乱さない粘土では c はせん断初期の非常に小さいひずみレベルで発 揮されるが，申のモビライズには大きいひずみを 必要とし, 同時には発揮されないことを指摘して いる. 同様な知見は, 国内外の多くの自然堆積砂 の実験結果でも報告されており 18)，19)，20)，21）, また本研究で使用した 2 種類の自然堆積砂磷士で も確認された 3)，4).

一方, Lee ${ }^{22)}$ は, 粒子破砕性の強いサクラメン 卜砂による拘束圧最大 $\sigma{ }_{3}^{\prime}=14 \mathrm{MPa}$ までの高圧 三軸圧縮試験を行い, 高圧時のせん断中の供試体 にも，ボンド䊗造が発達することを実験的に確か めている. $\left(\operatorname{coop}^{23)}\right.$ も, 同じく $\sigma_{3}{ }^{\prime}=8 \mathrm{MPa}$ まで のカーボナイト砂の三軸圧綰試験を行い, 試験後 の供試体が自立することから, 高圧時に粘着力の 発達することを指摘した.これとほぼ同様な知見 は, 既に三浦・山内 24)による, 豊浦砂供試体に ついての $\sigma_{3}{ }^{\prime}=49 \mathrm{MPa}$ の高拘束圧下の非排水三 軸圧縮試験の結果によっても指摘されている.

以上, 高圧時の粒子破砕とせん断中の粘着力の 発達についての研究を概観してみたが,ここで注 意しなければならないことは, 試験試料はすへてて $c=0$ の再調整試料であり, また材料により粘着 カの生じる圧カレベルの異なる点である. すなわ ち, せん断中の粘着力の発達には, 粒子の硬さや 粒径というような, 粒子そのものの構造特性と圧 カレベルも影敏することが予想される.

さらに，乱したスコリア地盤・乱した早川河口 砂地盤上で, 正方形基䂰を用いた支持力遠心実験 の結果, 换算基礎幅が $0.4 \mathrm{~m}$ の模型実験より得ら れた支持力係数は，これらの地盤とほぼ等しい内 部摩㨲角を有する豊浦砂地盤の実験結果に比へて, 特にスコリア地盤ではかなり大きい値となった。

これは乱した地盤であっても内部摩擦角成分のみ からでは, これらの支持力を十分説明できないこ とを示しており, 載荷に伴うフーチング直下での 地盤材料の粘着力の発達が示唆された25).

このように高拘束圧下でのせん断中に粘着力が 発達する原因として, 材料の粒子破砕, 化学的な 構造の変化, 水分の影留, 粒子表面同士の接着等 の指摘がなされている22)。しかしながら，実験 的に詳細な検討をした事例は少なく，高圧下での 粘着力の発達のメカニズムを明らかにすることは, 今後, 高圧力の作用する実地盤の支持力評価を行
う上でも重要であると考えられる.

そこで, 本研究では, 上記の点に着目して, 火 山性堆積物からなる 2 種類の自然堆積砂硯につい て, 拘束圧最大 $8 \mathrm{MPa}$ までの圧密排水三軸圧縮 試験を行い, 高圧下のせん断中の供試体にボンド 構造が形成された結果と，そのメカニズムについ て粒子破砕の視点より検討を行った.

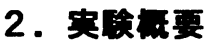

\section{(1) 試 料}

実験に用いた試料は, 静岡県東名足柄橋工事中 のニューマチックケーソン内の深さ約 $20 \mathrm{~m}$ の地 点より採取したスコリアと, 神奈川県小田原市の 西湘バイパス改筑工事中のニューマチックケーソ ン内の, 哚さ約7 mの地点より採取した早川河口 砂である.

スコリアは, 富士および箱根火山を起源とする 第四期更新世の火山噴出物からなる洪積堆積物で ある. スコリア粒子は多数の空隙を有し, 非常に アンギュラーな粒子構造をもつ材料である. 早川 河口砂は, 完新世に火山岩が早川を経由し, 河口 沖積堆積物として生成されたものである. 早川河 口砂の構成鉱物は, 硬度の低い斜長石が主成分で あり, 雲母も含有しており, やや風化作用を受け ている. 従って, スコリア, 早川河口砂とも現場 载荷試験, 支持力遠心実験, ならびに高拘束圧で のせん断試験時には, 强い粒子破砕を示すことが 明らかにされている1)，2)，3)，4)。

表一 1 に試料の物理・力学特性を, 図一 1 に試 料の粒径加積曲線を, 豊浦砂の結果とともにそれ ぞれ示している. スコリアは, 早川河口砂に比べ て均等係数、平均粒径とも大きい. また早川河口 砂は, 豊浦砂とほぼ等しい粒度分布を示している。

乱さない試料の低拘束圧で行った三軸圧縮試験 より得られた強度定数は, スコリアで $\mathrm{c}_{\mathrm{d}}=100$ $\mathrm{kPa}, \phi_{\mathrm{d}}=41.9^{\circ} \quad\left(\sigma_{3}{ }^{\prime}<294 \mathrm{kPa}\right)$, 早川河口 砂で $\mathrm{c}_{\mathrm{d}}=5 \mathrm{kPa} 、 \phi_{\mathrm{d}}=47.7^{\circ} \quad\left(\sigma_{3}{ }^{\prime}<98 \mathrm{kPa}\right)$ であ り，スコリアは強い固結性の材料である.

\section{（2）实験方法}

\section{a ）三軸圧綰試碓}

スコリアは, 乾燥状態で十分ほぐした後, 脱気 水で水浸させ負圧を加えて飽和させた．供試体は, 2 つ割れの㣚性モールド内（直径 $10 \mathrm{~cm}$, 高さ $20 \mathrm{~cm}$ ）に試料を5層に分けて注ぎ， 1 層 $40 \mathrm{~mm}$ で試 料上部より，板を直いた上から約1分間ハンドバ イブレーターにより締固めて作成した，その後， 
表一 1 試料の物理・力学特性

\begin{tabular}{|c|c|c|c|}
\hline Sample & Scoria & Hayakawa & Toyoura \\
\hline $\mathbf{G}_{8}$ & 2.85 & 2.76 & 2.64 \\
\hline $\mathrm{D}_{50}(\mathrm{~mm})$ & 1.15 & 0.17 & 0.18 \\
\hline $\begin{array}{l}\text { 細粒分 (Y) } \\
(\leqq 75 \mu)\end{array}$ & 2.4 & 2.1 & 10 \\
\hline$U_{c}$ & 4.25 & 1.73 & 1.52 \\
\hline$\theta_{\max }$ & 1.74 & 1.36 & 0.98 \\
\hline$\theta_{\min }$ & 1.17 & 0.85 & 0.61 \\
\hline
\end{tabular}

三軸压缩試験（乱さない試料）

\begin{tabular}{|l|l|l|l|}
\hline$\phi_{d}\left({ }^{\circ}\right)$ & 41.9 & 47.7 & - \\
\hline$c_{d}(\mathrm{kPa})$ & 100 & 5 & - \\
\hline
\end{tabular}

三軸压䑿試験（乱した試料）

\begin{tabular}{|l|l|l|l|}
\hline$\phi_{d}\left({ }^{\circ}\right)$ & 43.5 & 43.0 & 41.0 \\
\hline
\end{tabular}

$-20^{\circ} \mathrm{C}$ の冷凍庫内で凍結させて，ダイヤモンド カッターで成形した.ここで涷結する方法を用い た理由は，供試体密度を乱さない供試体と同等な 密度とすることを目標としたため, 三軸試験装置 のペディスタル上で供試体を作成することが困難 であったためである.

早川河口砂供試体は, 気乾状態の試料を 1 層 (30mm)あたり100回木桘でモールド側面に打撃を 加え，5層に分けて作成した.

スコリア供試体は, 直径 $10 \mathrm{~cm}$, 高さ $20 \mathrm{~cm}$, 早 川河口砂供試体は, 直径 $7.5 \mathrm{~cm}$, 高さ $15 \mathrm{~cm}$ の寸法 にそれぞれ成形した。供試体の相対密度は，スコ リアは95\%，早川河口砂は $84 \%$ として，乱さない 試料の密度の平均值とほほ同程度となるように調 整した。 また，比較のため，相対密度 $84 \%$ 豊浦 砂供試体についても実験を行った．締固め方法は, 早川河口砂と同一の方法である.

実験は，まず供試体に19.6 $\mathrm{kPa}$ の負圧を加えて， 2 時問程度二酸化炭素を回し，脱気水を十分に循 環させて B 值が0.95以上になるようにした。背 圧は98 kPaとした。なお, スコリア供試体は, 凍結状態にあるので, $19.6 \mathrm{kPa}$ の負圧を加えた 状態で一昼夜解凍した。，そして，所定の拘束圧で 一次圧密後，スコリアはひずみ速度 $0.2 \% / \mathrm{min}$, 早川河口砂と豊浦砂は $0.1 \% / \mathrm{min}$ でそれぞれ排水 せん断試験を実施した。

せん断試験終了後，供試体に乱れや振動を加え ないように留意して，メンブレンをカッターで割 き，供試体を $105^{\circ}$ Cの下で炉乾燥した。

三軸圧縮試験後の供試体は, 試験時の圧縮・せ ん断履歴の影䪄をある程度受けているものと考え られる，本研究では，特に粒子破砕の卓越した高 い拘束圧下において，せん断中に生じた粒子破砕

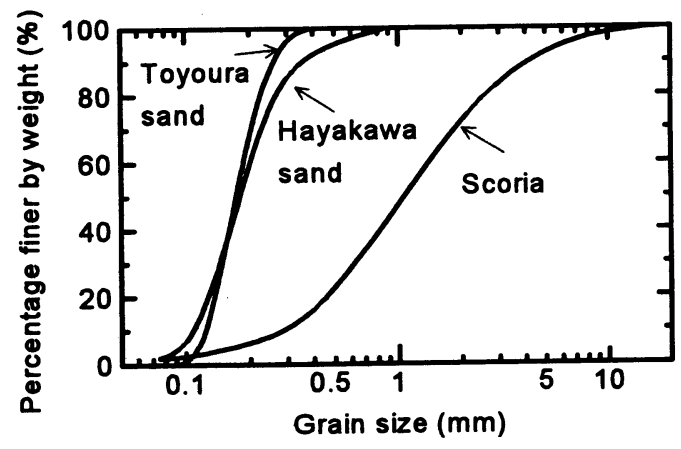

图一 1 試料の粒径加種曲線

と粘着力の関倸を調へることを目標とした。また， 本研究の試験試料であるスコリア, 早川河口砂で は, 高拘束圧の三軸圧縮試験で受けるせん断変形 には，粒子破砕の影䍌が卓越しているものと判断 した. このため, 三軸圧縮試験後の供試体を, 次 に述へる一軸圧縮試験, ブラジリアン試験, 水浸 試験に使用した。

\section{b ）一軸压樎試䖍}

スコリア, 早川河口砂ともに, せん断試験終了 後の乾燥供試体を, 成形せずにそのまま一軸圧縮 試験を行った。供試体寸法は，スコリアで直径約 $10 \mathrm{~cm}$ 、高さ約 $16 \mathrm{~cm}$, 早川河口砂と豊浦砂で直径 約 $7.5 \mathrm{~cm}$ 、高さ約 $12 \mathrm{~cm}$ である。一軸圧縮試験は, 三軸圧縮試験時の拘束圧が $1372 ， 2744 ， 4704 \mathrm{kPa}$ の試験後試料を用いて行った.

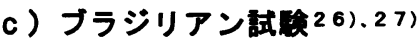

炬乾燥後の供試体は, スコリアは直径約 $10 \mathrm{~cm}$, 長さ約 $5 \mathrm{~cm}$, 早川河口砂は, 直径約 $7.5 \mathrm{~cm}$, 長さ 約 $3.5 \mathrm{~cm}$ の寸法にそれぞれ成形した。 その後, 直 径方向に荷重を加えるブラジリアン試験を行った. ブラジリアン試験は, 拘束圧 $294 \mathrm{kPa}$ から $6664 \mathrm{kPa}$ の範囲で実施した三軸圧縮試験後試料を用いて 行った.

\section{d）水瀑試( 28 ）}

水浸試験は，せん断試験終了後の供試体を用い て直ちに実施した。直径 $21 \mathrm{~cm}$, 高さ $17 \mathrm{~cm}$ のアク リル製の水槽内に供試体を固き， $3 \mathrm{~mm} / \mathrm{min}$ の浸 水速度で水を下から加えて水浸させ, 供試体が崩 れた時点の水位を测定した. 水浸試験は, 三軸圧 縮試験時の拘束圧が294〜4704 kPaの早川河口砂 


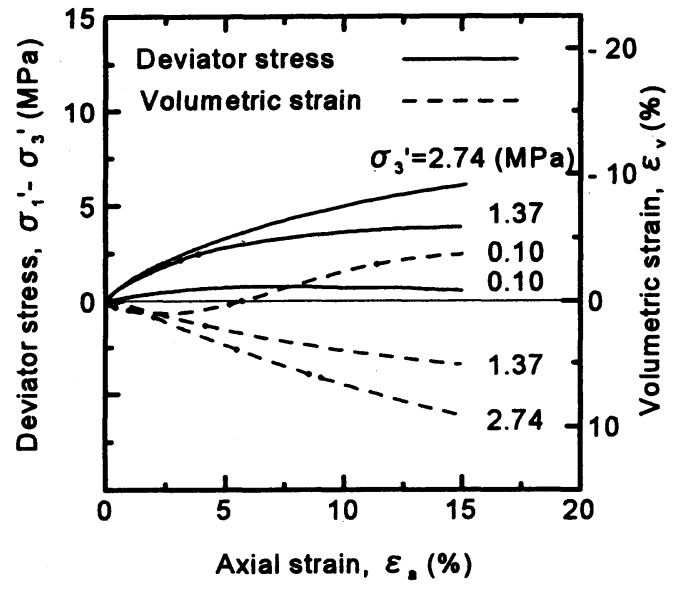

図ー2 スコリアの三軸圧縮試跧結果

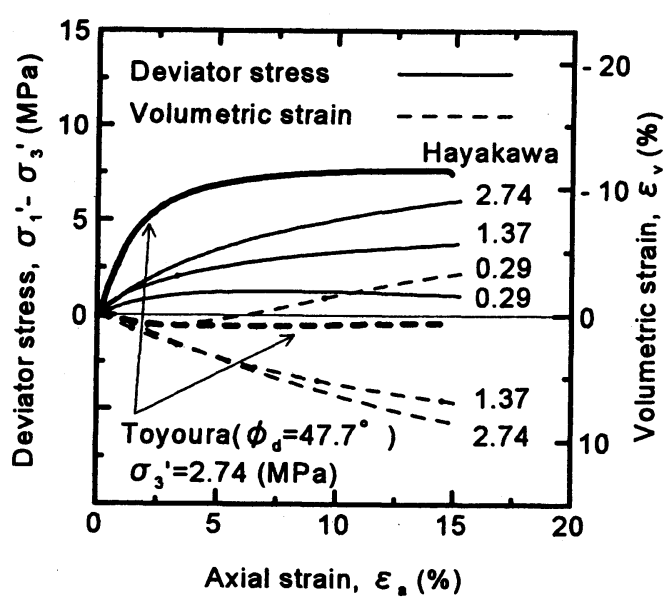

图一３三軸圧縮試跧結果

(早川河口砂, 豊浦砂)

の供試体を用いて行った.

\section{3. 实㰸結果と考察}

\section{（1）三軸圧綟試硢}

図一2は,スコリアの三軸圧縮試験結果を, 図 一 3は, 早川河口砂と豊浦砂の三軸圧縮試験結果 をそれぞれ示している.

スコリア, 早川河口砂とも, 主応力差一軸ひず み挙動は, 拘束圧レベルにより大きく変化してい ることがわかる. すなわち, せん断挙動が圧力レ ベルの增加とともに, 脆性的なものから延性的な ものへと変化している. また, $\sigma_{3}{ }^{\prime}=2.74 \mathrm{MPa}$ の軸ひずみ $15 \%$ の体䅡ひずみは，スコリア，早 川河口砂とも圧縮側に約 $10 \%$ にあて達しており， 体積圧縮性の著しいことがわかる，これは，同じ 拘束圧で実施した図一3に示す豊浦砂と早川河口 砂の三軸試験結果と比較してみても, 早川河口砂 はせん断中に体積圧縮傾向が強いことが明らかで ある.

2 つの試料は, 粒度分布がほほ等しく, ほぼ同 等な相対密度に調整し, 同一な試験方法で実験を 行ったので, これらのせん断挙動の違いは, 2つ の試料の粒子形状および粒子そのものの強さの相 違に依存すると考えられる，そしてこのことは， 次節に述へる粒子破砕程度の相違にも関係すると 考えられる.すなわち, 豊浦砂は, 破砕しにくい 硬い石英を主体とした鉱物構成であるのに対して, 早川河口砂の粒子は, 硬度の低い斜長石を主体と している. 従って, 49MPaの高圧下で生じる豊浦

砂の粒子破砕現象 ${ }^{24)}$ が, 早川河口砂では2.74MPa 程度の拘束圧の下で生じていることがわかる.

\section{（2）等方圧密，せん断による粒子破碎の評価}

粒子破砕を数量化する尺度は, これまでにいく つかの方法が提案されている ${ }^{29)}$. Marsal ${ }^{30)}$ は, 試験前後の試料について一組の粒度試験を行い, 各ふるいにおける試料の残留率について試験前後 の差を求め, それらの正值の和をもって粒子破砕 を表わす尺度とした。一方, 三浦・山内 ${ }^{6)}$ は, 粒子破砕前後における試料の表面樌の增加量が, 粒子破砕特性を表わす指標として有用であること を指摘している. 本研究では, 粒度試験により簡 便に求めることができ，これまでに比較的良く利 用されている指標として, Marsa1の粒子破砕率 を用いることとした.

そこで，等方圧密・せん断試験による粒子破砕 の程度を調へるために, 試験後の試料をふるい分 けして粒度分布を求めた. 試験後スコリア試料に ついて, 試験前試料と粒度分布を比較した結果を 図ー4に示す。

図より，等方圧密時とせん断試験時の粒度分布 を比較すると, 等方圧密後の粒径加積曲線は試験 前試料とほとんど変化していないことがわかる.

これに対して, せん断試験時では, 拘束圧の増加 とともに粒度分布は左側へシフトし，粒子破砕が 生じたことを示しており，細粒分含有率も增加す る傾向を示している. 従って, 粒子破砕は、主に せん断中に起こったものと考えられる.

図一5は, Marsalの粒子破砕率 $\mathrm{B}_{\mathrm{M}^{30}}{ }^{30}$ と破壊時 平均主応力 $\mathrm{p}_{\mathrm{f}}{ }^{\prime}$ との関保を示したものである、ス 


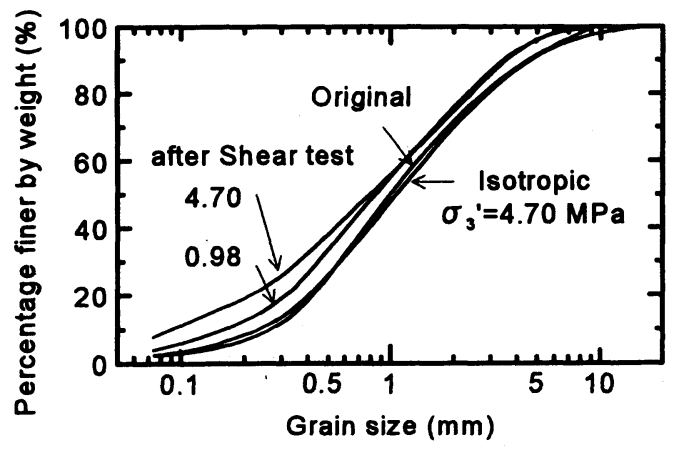

図一4 等方圧密, せん断による粒度分布の変化 (スコリア)

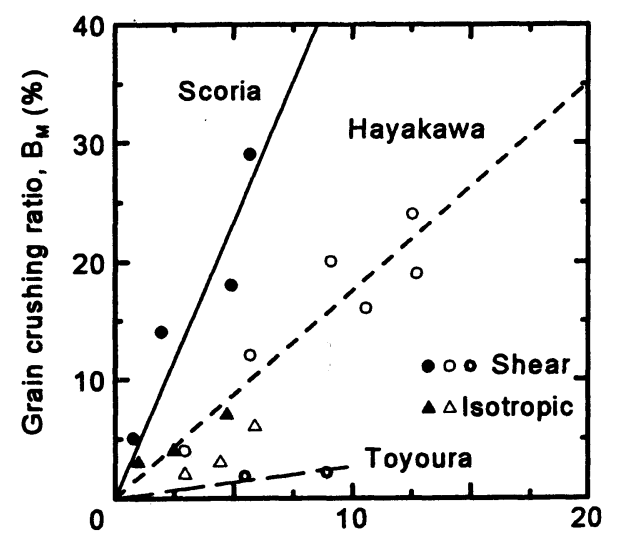

Effective mean stress at failure, $p_{f}^{\prime}(M P a)$

図-5粒子破砕率と破維時平均主応力の関係

コリア，早川河口砂ともに $\mathrm{p}_{\mathrm{f}}$ が増加すると $\mathrm{B}_{\mathrm{M}}$ もほぼ比例して增加している． $\mathrm{p}_{\mathrm{f}}^{\prime}=10 \mathrm{MPa}$ まで は, 豊浦砂には粒子破砕はほとんど認められず, スコリア, 早川河口砂の破砕程度の大きいことが 分かる.また, 等方圧密による粒子破砕程度は, せん断時に比へて著しく低くなっている．従って， 粒子破砕の程度は, せん断時に作用する平均主応 力の大きさに依存しているものと考えられる.

さらに, スコリアの方が早川河口砂よりも直 線の傾きが急であり，粒子破砕の程度の大きいこ とが分かる.これには，主に2つの原因が考えら れる. 1 つには, スコリアが早川河口砂よりも多 孔質な材料からなるということである.すなわち, スコリアは，粒子の骨格自体の強さが早川河口砂 よりも脆弱なため, 同等の応力が作用した場合, スコリアの方が早川河口砂に比へ，粒子破砕をよ り多く起こしやすいと考えられる。 もう一つは,

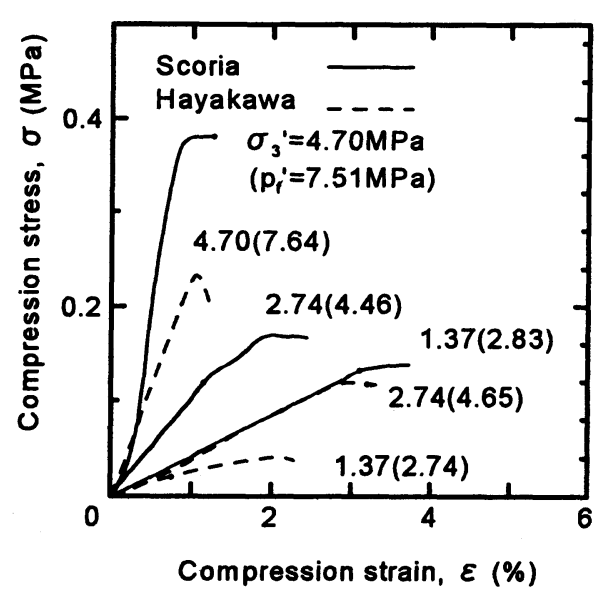

图一6 せん断試殹後試料の一軸圧縮試医結果

スコリアの粒径が早川河口砂のそれよりも大きい ことである. 粒径が大きい程粒子接点数が少なく なり，一つの粒子に対してより大きな力が加わる ため，顕著な粒子破砕が生じるものと考えられる.

\section{（3）一軸压綰試食}

三軸圧縮試験終了後の供試体をそのままの状態 で, 一軸圧維試験, ブラジリアン試験を行う場合 には, 試験開始前までに, 含水比等の変化により 供試体が不飽和状態となり, サクションの影響が 出ることが予想された. また, 本研究では, 乾燥 状態という同一な条件で各供試体を比較すること、 および粒子破砕に起因した粘着力の発達を調べる ことを試験目的とした。このため, 一軸圧縮試験, ブラジリアン試験は, 三軸圧縮試験終了後に炉乾 燥した供試体を用いて実施した。

図一6は，一軸圧縮試験の結果より得られた応 カーひずみ曲線である. 三軸圧緥試験時の破壊時 平均主応力 $\mathrm{p}_{\mathrm{f}}$ 'が大きい程, より脆性的な応力一 ひずみ挙動を示す曲線となっている. 一軸圧縮試 験は, いずれも供試体に縦方向のクラックが生じ た時点で終了した。

図一7は, $p_{f}^{\prime}$ と一軸圧縮強度 $q_{u}$, 変形俰数 $\mathrm{E}_{50}$ の関係を示している. $\mathrm{p}_{\mathrm{f}}^{\prime}$ が大きい程, $\mathrm{q}_{u}$, $\mathrm{E}_{50}$ が大きいことが明らかである.

スコリア, 早川河口砂ともに, 乱した供試体を 使用したので, 供試体作成時には粘着力は存在し ないと考えられる．ところが, せん断試験終了時 の供試体は, 自立できるようになっており, その 


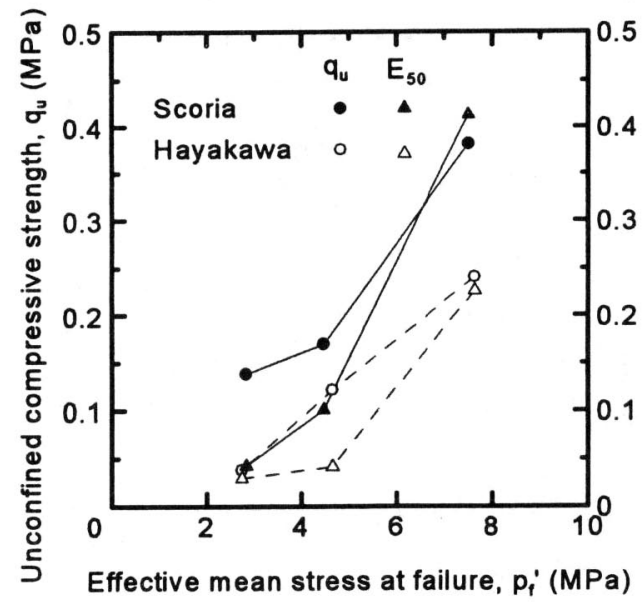

図一 7 一軸圧縮強度, 变形係数と $\mathrm{p}_{\mathrm{f}}$ 'の関保

表一 2 各試料の $(\mathrm{qu} / 2) / \mathrm{p}_{\mathrm{f}}^{\prime}$ の比較

\begin{tabular}{|c|c|}
\hline 試料 & $(\mathrm{qu} / 2) / \mathrm{p}_{\mathrm{f}}^{\prime}$ \\
\hline $\begin{array}{c}\text { Sacramento River } \\
\text { Sand }\end{array}$ & $0.005-0.008$ \\
\hline Toyoura ${ }^{24)}$ & $0.001-0.003$ \\
\hline Scoria & $0.019-0.025$ \\
\hline Hayakawa & $0.011-0.016$ \\
\hline
\end{tabular}

$\mathbf{p}_{\mathbf{f}} \mathbf{y}^{\prime}$ : せん断時の最大平均主応力

$\mathrm{q}_{\mathrm{u}}$ : 一軸圧縮強度

後，炬乾燥させた後でも自立していた．このこと から, 供試体の自立は, 毛管水による吸着現象に よるものではなく，固結力が原因と考えられる.

なお, 炉乾燥のプロセスで粒子接点での軽いセ メンテーションなどによる結合力が発達している 可能性も考えられる. しかしながら, 図一7より せん断中の応力レベルが高い程, せん断試験後試 料の一軸圧縮強度, すなわち粘着力の值が大きい ことがわかる. 従って, せん断中に粘着力が発達 した結果, この固結力が形成されたものと推定さ れる。これに対して, 豊浦砂供試体は, 三軸圧縮 試験終了後間隙に水分を保有していた時点では自 立していたが, 炬乾燥後には崩壊した. 従って, 豊浦砂は $\sigma_{3}{ }^{\prime}=4704 \mathrm{kPa}$ の拘束圧下のせん断中に は, 粘着力が発達しなかったものと考えられる.

表一 2 は, 一軸圧縮試験より求めた一軸圧縮強 度 $\mathrm{q}_{\mathrm{u}}$ の $1 / 2$ を, 三軸圧縮試験中の破壊時平均有 効主応力 $\mathrm{p}_{\mathrm{f}}$ 'で除して, 正規化した $\left(\mathrm{q}_{\mathrm{u}} / 2\right) /$ $\mathrm{p}_{\mathrm{f}}{ }^{\prime}$ をまとめたものである. $\left(\mathrm{q}_{\mathrm{u}} / 2\right) / \mathrm{p}_{\mathrm{f}}{ }^{\prime}$ は, スコリアの方が早川河口砂に比べてやや大きい值

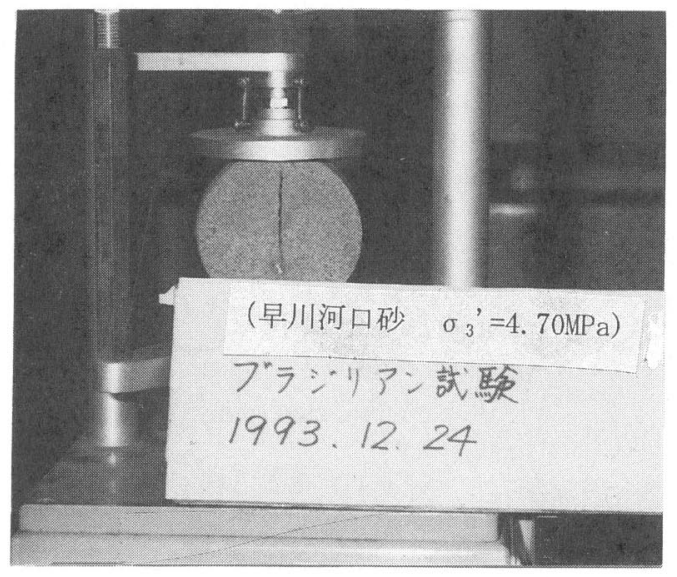

図－8ブラジリアン試験後の供試体破壤状況 (早川河口砂 $\sigma_{3}{ }^{\prime}=4.7 \mathrm{MPa}$ )

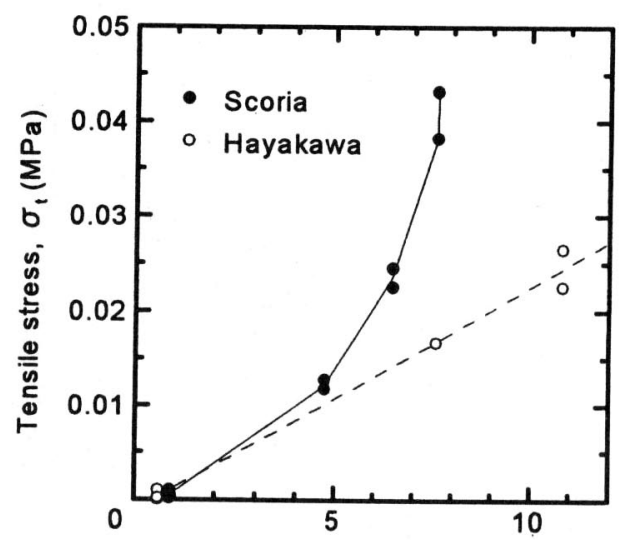

Effective mean stress at failure, $p_{f}^{\prime}(\mathrm{MPa})$

図－9引張り强度と破壊時平均主応力との関係

を示している.このことから、( $\left.\mathrm{q}_{\mathrm{u}} / 2\right) / \mathrm{p}_{\mathrm{f}}$ は, 粒子破砕程度の顕著な方がより大きくなるものと 推定される.

\section{(4) ブラジリアン試験}

図ー8は, ブラジリアン試験により破壊した早 川河口砂供試体の状況を示したものである。一軸 圧縮試験の場合と同様に, 供試体は, 繸方向にク ラックが見られる脆性的な破壊形状を示している.

図ー9は, ブラジリアン試験の結果より求めた 引張り強度 $\sigma_{\mathrm{t}}$ と破壊時平均主応力 $\mathrm{p}_{\mathrm{f}}$ ' の関係で ある. 一軸圧縮試験の結果と同様に, $\mathrm{p}_{\mathrm{f}}$ が大き い程, 引張り強度は大きくなる傾向が認められる. 


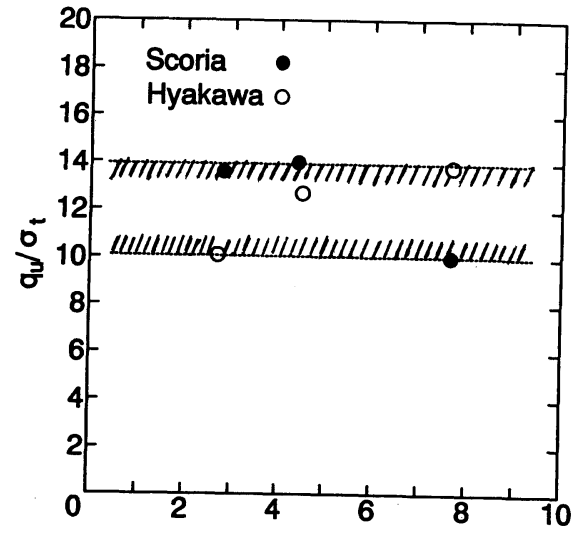

Effective mean stress at failure, $p_{f}^{\prime}(\mathrm{Mpa})$

图ー $10 \quad q_{u} / \sigma_{t}$ と $p_{f}^{\prime}$ の関保

図一１0は, 引張り強度 $\sigma_{\mathfrak{t}}$ に対する一軸圧縮 強度 $\mathrm{q}_{\mathrm{u}}$ の比 $\mathrm{q}_{\mathrm{u}} / \sigma_{\mathrm{t}}$ と, 破壊時平均主応力 $\mathrm{p}_{\mathrm{f}}{ }^{\prime}$ と の関係を示している， $\mathrm{q}_{\mathrm{u}} / \sigma_{\mathrm{t}}$ は, スコリア, 早 川河口砂とも10〜14の值を示し, これは試料, および拘束圧レベルによらず概ね一定の值をとっ ている. Cloughら ${ }^{18)}$ の研究では, 中位の固結砂 で $\mathrm{q}_{\mathrm{u}} / \sigma_{\mathrm{t}}=10$ との報告がなされており, 今回の実 験結果とほぼ一票している.

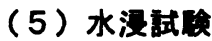

図一 11 は, 早川河口砂の水浸試験結果を示し たものである. 図の縦軸は, 供試体初期高さ $\mathrm{H}_{0}$ に対する崩壊水位 $\mathrm{H}_{\mathrm{f}}$ の割合を, 横軸は, 三軸圧 縮試験の破壊時平均主応力 $\mathrm{p}_{\mathrm{f}}$ 'をそれぞれ示して いる．図より $\mathrm{p}_{\mathrm{f}}$ 'が大きい程, 崩壊時の水位は高 いことがわかる.なお, 拘束圧が $2704 \mathrm{kPa}$ 以上 で実施した三軸圧縮試験後供試体では，供試体が 完全に水没した後も24時間以上自立していた.

浸水供試体は，飽和に近い状態にあるものと考え られる. 以上の点と図内に示した $\mathrm{q}_{\mathrm{u}} / 2$ と $\mathrm{p}_{\mathrm{f}}$ ' との関係を考虑すれば，供試体の自立は，せん断 中に発達した粘着力の影警によること，およびそ の程度は拘束圧レベルに比例することが再確認さ れる。

\section{（6）粘前力の発遠と粒子破碎との閏係}

Marsa1の粒子破砕指標は, 粒子破砕程度を定 量的に評価することの難しいことが，これまで指 摘されている6) 。しかしながら, 今回の実験結果 より, 拘束圧レベルの增加に対して, 粒子破砕程 度と粘着力の大きさがいずれも比例的に增加する

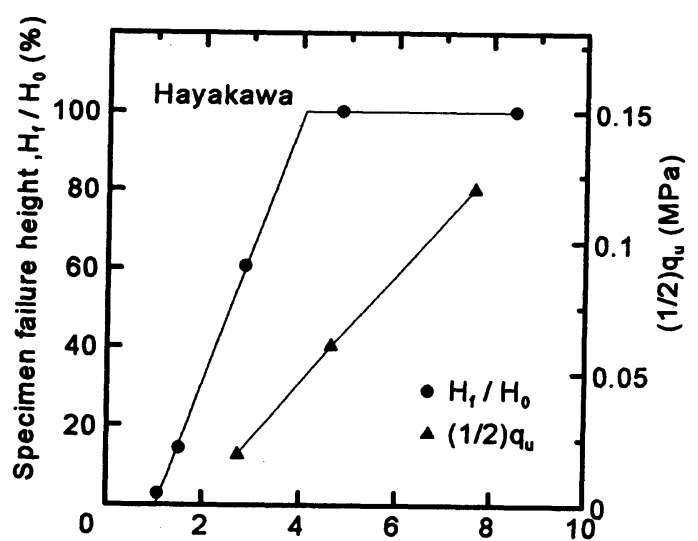

Effective mean stress at failure, $p_{f}^{\prime}$ (MPa)

图一 11 崩境水位および $\mathrm{q}_{\mathrm{u}} / 2$ と $\mathrm{p}_{\mathrm{f}}$ 'との関俰

ことを定性的に示すことができた.

そして, 砂喽土の要素において, 拘束圧最大 8 $\mathrm{MPa}$ 程度までのせん断中に, 粘着力の発達するこ とが示された.さらに, 粘着力の発達と粒子破砕 の程度は, いずれも三軸圧縮試験の破壊時平均主 応力 $\mathrm{p}_{\mathrm{f}} \mathbf{r}^{\prime}$ と比例関保にあることから, 高圧下での 粘着力の発生メカニズムの主な原因は, 粒子破砕 にあると考えられる。

一方, 高圧での粒子破砕の程度は、水分に関係 することも指摘されている（Miura and Yamanouchi ${ }^{24)}$, Sowers, et al. ${ }^{31)}$ ). 従って, 高圧力下での土の構造特性の変化は, せん断試験 時の排水条件も影䠹すると考えられる. また, ス コリア, 早川河口砂と豊浦砂との比較に見られる ように, 粘着力の発達の程度は, 材料そのものの 特性と作用する圧カレベルに影響することが明ら かにされた。

早川河口砂地盤上で実施した現場載荷試験のせ ん断層の観察 ${ }^{2)}$ からも, フーチング直下主值域 のせん断層部分は, 粒子破砕により周辺部に比べ て負のダイレイタンシーを示していることが確認 された.さらに，顕微鏡によるせん断居の詳細な 観察結果からは, 破砕した細かい粒子が大きい粒 子表面に多数付着し, 粘性をおびている様子も確 認された ${ }^{25)}$. これは, 要素で今回実証された高圧 下でのせん断中の粘着力の発達が, マスでの載荷 に伴うフーチング直下のすべり面近傍でも生じて いることを示唆するものといえる.

従って, 今後はさらに, 支持力問題などに関し て詳細な検討を行う予定である. 


\section{4. 结}

本研究より得られた主な結論は, 以下の通りで ある。

（1）粒子破砕性である自然堆積砂礫試料のスコリ ア, 早川河口砂では, 拘束圧 $\sigma_{3}{ }^{\prime}=8 \mathrm{MPa}$ 程度まで の圧カレベルにおいて，せん断中の供試体内に粘 着力が発達することが明らかにされた.

(2) 三軸圧綰試跧後供試体で実施した一軸圧縮試 験, ブラジリアン試験, 水浸試験の結果より, せ ん断時に発達する粘着力の程度は，せん断中に供 試体が受ける平均主応力が大きいほど著しくなる ことが示された.

（3）せん断中の粘着力の発達の程度は, 試料の粒 子特性, 寸なわち粒子形状, 粒径, 鉣物構成によ り異なることが明らかにされた。

（4）一軸圧縮強度 $\mathrm{q}_{\mathrm{u}}$ と引張り強度 $\sigma_{\mathrm{t}}$ の関係を求 めると, $\mathrm{q}_{\mathrm{u}} / \sigma_{\mathrm{t}}$ の值はスコリア, 早川河口砂と も $\mathrm{q}_{\mathrm{u}} / \sigma_{\mathrm{t}}=10 \sim 14$ となり, 試料, 拘束圧レベルに よらずほぼ一定の值をとることが分かった。

(5) 粘着力の発達と粒子破砕の程度は, いずれも 破壊時平均主応力と比例関倸にあることから，ス コリアと早川河口砂のせん断中の粘着力の発達の 主因は，粒子破砕にあると考えられる.

\section{参考文献}

1）前田良刀, 日下部 治, 大内正敏：密なスコリア 層における大型三次元基砋の支持力特性, 土木 学会論文集, No. 430/III-15, pp. 97-106, 1991.

2）大内正敏, 日下部 治, 萩原敏行, 阿部慎太郎 :

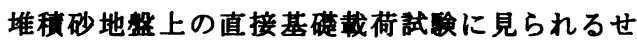
ん断層の発達と粒子破砕, 土木学会論文集, No. 487/III-26, pp. 207-216, 1994.

3）日下部 治, 前田良刀, 大内正敏, 萩原敏行: 不 拱乱スコリアの强度・変形特性と摬乱の影需, 土木学会論文集, No. 439/III-17, pp. 69-78, 1991.

4) 萩原敏行, 日下部 治, 大内正敏, 岡本圭司: 構 造特性に着目した不擋乱早川河口砂の強度・变形 特性, 土木学会論文集, No. 487/III-26, pp. 119128, 1994.

5）三浦哲彦，山内豊聡：高拘束圧下における標準砂 の排水せん断特性について, 土木学会論文報告 集, 第193号, pp. 69-79, 1971.

6）三浦哲彦，山内豊聁：砂のせん断特性に及ぼす粒 子破碎の影㛭, 土木学会論文報告集, 第260号, pp. 109-118, 1977.

7) 三浦哲彦：杭先端付近における砂の粒子破砕と杭 の支持機棬，土と基礶，Vol. 32，No.6， pp. 45-50, 1984.

8) Leroneil, S. and Vaughan, P. R.:The general and congruent effects of structures in natural soils and weak rocks, Geotechnique, Vol. 40, No. 3, pp. 467-488, 1990.

9) Tsuchida, T., Kobayashi, M. and Mizukami, J. : Effect of aging of marine clay and its duplication by high temperature consolidation, Soils and Foundations, Vol. 31, No. 4, pp. 133-147, 1991.

10) Maccarini, M. :Laboratory studies of weakly bonded artificial soil, Ph.D.thesis, University of London, 1987.

11) Yoshimi, Y., Tokimatsu, K. and Hosaka, Y. : Evaluation of liquefaction resistance of clean sands based on high-quality undisturbed samples, Soils and Foundations, Vol. 29, No. 1, pp. 93-104, 1989.

12) Ishihara, K. and Hsu, H. L. :Considerations for landslides in natural slopes triggered by earthquakes, Proc. of JSCE, No. 376, pp. 1-16, 1986.

13）鳥居 㣚, 中村博久, 三笠正人：低応力一面せん 断試耠結果を用いた模型斜面の安定計算, 第44 回土木学会年次学術䛍演会, pp. 544-545, 1989.

14）福島伸二：不䬲和砂兵土の低拘束圧項域における 强度特性, 第27回土質工学研究発表会, pp. 607$608,1992$.

15）蓒國成, 佐藤㣚司, 龍岡文夫, 田村重四郎：低 拘束压下における不的和砂の強度变形特性, 生産 研究, 34巻9号, pp. 35-38, 1982.

16）朴春植, 龍岡文夫：締固めた不飽和稲城砂の平 面ひずみ圧縮試監, 第24回土犋工学研究発表会, pp. 505-508, 1989.

17) Bjerrum, L. :Problems of soil mechanics and construction on soft clays and structurally unstable soils (collapsible, expansive and others), Proc. ICSMFE, Session 4, pp. 111-159, 1973.

18) Clough, G. W., Sitair, N., Bachus, R. C. and Rad, N.S.: Cemented sands under static loading, Journal of Geotechnical Engineering, ASCE, Vol.107, No.GT6, pp. 799-817, 1981.

19) O'Rourke, T.D. and Crespo, E. : Geotechnical properties of cemented volcanic soil, Journal of Geotechincal Engineering, ASCE, Vol.14, No. 10, 
pp. 1126-1147, 1988.

20) Hul1, T.S., Poulos, H. G. and Alehossein, H. :The static behaviour of various calcareous sediments, Engineering for Calcareous sediments, ed. Jewell and Andrews, Balkema, pp. 87-96, 1989.

21）春山元寿：䛍座 c と $\phi$ を考える，土と基碳， Vol. 23, No. 6, pp. 67-74, 1975.

22) Lee, K. L. :Adhesion bonds in sands at high pressures, Proc. of ASCE, Vol. 103, No. GT8, pp. 908-913, 1977.

23) Coop, M. R. :The mechanics of uncemented carbonated sands, Geotechnique, Vol.40, No. 4, pp. 607-626, 1990.

24) Miura, N. and Yamanouchi,. T. :Compressibility and drained shear characteristics of a sand under high confining pressures, Faculty of Engineering Report, Yamaguchi University, Tokiwadai, Japan, Vol. 1, No. 2, 1973.

25）萩原敏行：固結性自然堆積砂磼の強度・变形特性 とその支持力に関する実醶的研究，東京工業大
学学位論文, 1994.

26）土質工学会相 : 土梊試会の方法と解説, 土梊工学 会, 1990 .

27）村田秀一, 山内豊跨：乱さないシラスの強度特性 の要因について，土質工学会站文報告集， Vol. 17, No. 3, pp. 81-91, 1977.

28）足立格一郎, 圄田紘史, 服部一利, 井浑勝, 古 川雅宣：砂梊試料の「見かけ」およひ「真」の 粘着力と液状化强度，第25回土啠工学研究発表 会, pp. 765-766, 1990 .

29）福本武明：粒子破砕の程度を示す指妳 , 土と基礶, Vol. 29, No. 12, pp. 64-65, 1981.

30) Marsa1, R. J. :Discussion of shear strength, Proc. of the 6th ICSMFE, pp. 310-316, 1965.

31) Sowers, G.F., Williams, R.C. and Wallace, T.S. :Compressibility of broken rock and the settlement of rockfills, Proceedings of the 6th International Conference on Soil Mechanics and Foundation Engineering, Montreal, Canada, Vol. II, pp. 561-565, 1965.

(1995.3.9 受付)

\section{THE PARTICLE CRUSHING AND FORMATION OF ADHESION BONDS - IN NATURALLY DEPOSITED SANDS UNDER HIGH PRESSURE \\ Toshiyuki HAGIWARA, Kohji KITAZAWA and Osamu KUSAKABE}

This paper describes the observed formation of adhesion bonds during triaxial compression tests on naturally deposited sands under high confining pressures from $1000 \mathrm{kPa}-8000 \mathrm{kPa}$. The experimental results show that the degrees of particle crushing and adhesive bonding inrease with increasing confining pressure. It was also found that the degree and permanence of bonding vareid with the type of soil or soil mineral and was strongly affected by the amount of the particle crushing during shearing. 